\title{
Japanese Learners' Consciousness Toward English: When Do They Begin to Like or Dislike English?
}

\section{Sumie Matsuno}

\section{Aichi Sangyo University College}

\begin{abstract}
This paper provides a review of research addressing when students begin to like or dislike English, when they obtain or lose their motivation for learning English, and the reasons associated with their preferences and motivation regarding the language. It also includes a discussion of the findings of a qualitative survey conducted by the author, which indicates that the first and the second grades of junior high school are probably serious turning points of their consciousness toward English. The second biggest turning point is probably the first half of the first grade of high school. Once they have difficulty in learning English and begin to hate English, their feelings continue, even at the university level. The reasons for students' dislike of English are often related to their difficulty with the language. For example, studying English is to memorize sentences and words, and learning English grammar is very difficult.
\end{abstract}

本論では、生徒が英語を好きになり始めたり嫌いになり始める時期や その動機、理由について過去の研究結果を調査している。また40名の大 学1年生を対象にした質的調査を行った結果を述べている。この質的調 査の結果はこれまでの研究結果を裏付けるもので、まず中学 1 年と 2 年の 時期、次に高校1年の前半の時期が、英語に対する意識の最も重要なタ一 ニングポイントであることがわかった。また一度嫌いになるとその気持ち は大学生になっても続く傾向にある。嫌いになる要因としては英文や英 単語の暗記、文法の難しさがあげられる。

W hen do students begin to like or dislike English? When are they motivated or demotivated to study the language? There are several factors that may contribute to a student's motivation to learn a second language. Learners' motivation and contributing factors are often researched quantitatively using questionnaires. However, each student has different characteristics, which are sometimes difficult to examine using quantitative methods (Dörnyei, 2009; Suemori \& Sasajima, 2016). This paper provides a review of research addressing when students begin to like or dislike English, when they obtain or lose their motivation for learning English, and the reasons associated with their preferences and motivation regarding the language. It also includes a discussion of the findings of a qualitative survey conducted by the author.

\section{When Do Students Start to Like or Dislike English?}

In 2011, Japanese elementary schools formally began implementing English education. However, English education in elementary schools had been provided to students and was considered a part of comprehensive school hours since 2002 with $97.1 \%$ of elementary schools offering English classes in 2007 (Oka \& Kanamori, 2009). According to Sakai (2009), as a result of the early introduction to English, 11.7\% of students expressed negative feelings toward English before entering junior high school. Without any English education in elementary school, would those students have looked forward to learning English at junior high school? This was supported by Hasegawa (2013), whose research showed that across three elementary schools, $10-35 \%$ of students did not like English. Matsumiya (2012) found that approximately $70 \%$ of fifth and sixth grade elementary school students liked English, but only $54.4 \%$ of fifth graders and $53 \%$ of sixth graders were looking forward to taking English classes in junior high school. He concluded that this result should be considered seriously to connect English education in elementary school with that in junior high school. Overall, whether English classes in elementary school may have a positive impact on students' feelings toward English is still controversial.

Let us now look at students' feelings toward English in junior high school. Yamamori (2004) found that approximately $90 \%$ of students were motivated to study English at the beginning of junior high school; however, this percentage dropped to about $60 \%$ in the middle of the second term of the first grade. Sakai (2009) asked 2,967 junior high school students to identify their favorite subject and found that English was in the eighth place among nine subjects. Regarding the question of when they were most motivated to study English, $43.6 \%$ of the students answered that they were most motivated at the beginning of junior high school (Sakai, 2009). This was supported by Benesse Educational Research and Development Institute (2014), indicating 
that the students began to have an aversion to English between the first half of the first grade and the latter half of the second grade in junior high school. In another study, in 2015, Benesse found that only $50.4 \%$ of students liked English, which was the lowest rating among ten subjects. The findings of these studies suggest that many students begin to dislike English during junior high school. Furthermore, once the students begin expressing such feelings, they continue to feel the same even when they are studying at the university level (Kiyota, 2010).

Just a few attempts have been made to ask high school or university students when they began to like or dislike English. Benesse Educational Research and Development Institute (2014) found that, in addition to the period between the first half of the first grade and the latter half of the second grade in junior high school, the first half of the first grade of high school was a big turning point from them liking to disliking English because approximately $35 \%$ of students began to dislike learning English. Sawyer (2007) examined 120 university students' motivation when they were in junior high and high schools. He found that motivation was high at the beginning of junior high school and then decreased. It also decreased from the first to the second year in high school and increased in the third year, and then decreased once again after entering a university. Suemori and Sasashima (2016) chose two students out of 126 university students and interviewed them. One student liked English even before entering junior high school because her family encouraged her to study English. The other student attended an English conversation school during elementary school, but she did not like English and still had some difficulty with learning English even as a university student. Suemori and Sasashima suggested that "each learner can have his or her own unique characteristics" of how he/ she is motivated or demotivated to study English (p. 129). Kikuchi and Sakai (2016) researched factors affecting changes in English learning motivation among university students and found that students' motivation to study English began when they were in the third grade of both junior high school and high school. However, during the first grade of both junior high and high school, they became demotivated to study English.

\section{Why Do Students Change Their Attitudes Toward English?}

Understanding why students change their attitudes toward English is just as important as knowing when students experience this change. Hasegawa (2013) conducted research with 95 elementary school students and found that $81 \%$ of the students liked English because they could sing English songs, enjoy games, talk with their friends in English, and learn about other cultures. On the other hand, $18 \%$ of the students disliked English because they could not read or understand English and they could not communicate with their friends in English. Even at the elementary school level, students' competence toward English is arguably related to their disinclination for English.

Yamamori (2004) found that junior high school students started to dislike English because it became difficult for them. More specifically, he also noted that they could not obtain favorable scores on mid-term or final tests. For instance, Yamamori's study found that the mean points of English exams dropped dramatically between the first and the second terms in the first grade of junior high school, which was typical in all junior high schools. Sakai (2009) surveyed junior high school students about the reasons why they started to dislike English and found that English grammar was difficult for most of them (78.6\%). Koike (2013) also recognized that teachers and positive experiences toward English affected students' preferences for English. An example of this was found in a study by Tatsuno (2009), who noted that some of the reasons for liking English were that students were praised by teachers, or they earned good scores on English tests. In a similar study, Tokuhashi and Mizuochi (2017) followed the progress of lower-placed students in first grade English classes and found that it was possible for them to make progress in their learning motivation when the teachers gave individual students praise and advice. According to Kikuchi and Sakai (2016), students were motivated to study English because they had to take entrance examinations to get into a high school or university. However, their motivation declined because they had too many assignments, and the types of teaching styles and textbooks were not appropriate for them (Kikuchi \& Sakai, 2016). These results indicated that students' motivation to study or like English were related to teachers, classes, interests in English and other cultures, and entrance exams. Their incompetence in English contributed to their dislike of English or demotivation to study the language.

\section{The Current Qualitative Survey}

If teachers know when and why students begin to like or dislike English, they can take the appropriate measures to prevent students from disliking English. A survey of attitudes toward English was carried out among students attending one of Japan's national universities. The participants included 40 
Japanese students who were majoring in engineering or nursing and took English classes as a part of their liberal arts studies. They were asked whether or not they liked English, when they started to like or dislike English, and the reasons for their preferences. They were also asked to report the specific time when their feelings toward English changed and the reasons for the change. The students could write their answers freely on paper.

The first question used a Likert scale, from 1 to 5 , to obtain the degree to which students liked English, where 1 indicated that they disliked English and 5 indicated that they liked English. After responding to the Likert scale, students were asked when they started to like or dislike English and what caused their attitudes toward English to change.

Only two students (5\%) selected " 5 ", and nine students (22.5\%) selected " 4 ". These responses indicated that these students liked English. Their open-ended comments revealed that they started to like English from the beginning of their study of the language and still felt that way at the university level. Various reasons why they liked English were reported and thus divided into three types. The first is that they liked English classes and/or teachers (type A). The second type were those who liked to have conversations with foreigners (type B). The final type were those who could do well in English (type C). It is interesting to note that the two most common reasons (given by 10 out of 11 students) were reported more frequently than the third most common reason (reported by three students). Some students wrote a couple of reasons, so the number of reasons is not equal to the number of the students. Examples of the students' reasons include:

When I was a junior high school student, I liked reading in English in class. I enjoyed having conversation in English in class. (type A)

I liked listening to songs with English lyrics in class at junior high school. So I came to like English. (type A)

When I traveled abroad, I was able to use English. (type B)

My grades in English were always good in my school days. (type C)

I liked my English teacher when I was a junior high school student, and I came to like English from that time. (type A)

I used English in foreign countries, which made me excited. (type B)
Although students could write whatever they wanted in response to the open-ended question, their comments were similar. These comments are consistent with Koike's (2013) findings regarding positive experiences toward English.

Fourteen students (35\%) selected " 3 " on the Likert scale. They neither liked nor disliked English and many of them were unsure about when they started to have this feeling. However, six out of 14 students (42\%) reported that their feelings toward English had not changed since junior high school. Their reasons were often very similar: English is important, but they were not good at it. Ten out of 14 students reported that they are not good at English. The following are examples of comments from these students:

When I don't understand, I don't like English. When I understand, I come to like English.

I am not good at English, but it is useful to learn English.

When I go abroad, I want to speak English, but I am not good at it.

To learn a foreign language may be enjoyable, but I am not good at it.

I want to improve English, but I can't.

These comments were consistent with Benesse Educational Research and Development Institute (2014), which reported that $92.5 \%$ of junior high school students and $91.6 \%$ of senior high school students recognized how useful English is in society. The current survey also showed that the students who neither liked nor disliked English still recognized the usefulness of English.

Seven students (17.5\%) selected "2" on the Likert scale, and eight students (20\%) selected " 1 ". Those 15 students did not like English. Ten students (67\%) reported that they started to dislike English when they were in junior high school, five students began to dislike English when they were in the first grade, and the remaining students began to dislike the language when they were in the second grade. Five students (12.5\%) started to dislike English when they were in the first grade of high school. These results are reinforced by the findings of Benesse Educational Research and Development Institute (2014), which said that during the period between the first half of the first grade and the latter half of the second grade in junior high school and in the first half of the first grade of senior high school, students started to dislike English. Interestingly, the students in the current study reported that they were poor at 
English. Some of their comments include:

I was not good at memorizing English vocabulary.

It was hard to learn grammar.

In high school, vocabulary and grammar became so hard for me.

I realized that I was not good at speaking in English.

I could not hear or read long sentences in English.

I had to study English even though I did not like it so much.

I don't like memorization, and studying English is like memorization in junior high and senior high schools.

I liked English in junior high school, but I started to dislike it in senior high school, because it became too difficult for me.

Concerns about English competence are evident in all of their comments. This supports the findings of previous studies (Kikuchi and Sakai, 2016; Koike, 2013; Sakai, 2009; Tatsuno, 2009; Yamamori, 2004).

\section{Conclusion}

The current survey was conducted with a small number of students (40 students) and a narrow subset, so the results cannot be generalized. On the other hand, we still can notice some tendencies, which can be supported by the previous studies. The current survey and previous studies show that students often begin to dislike English when they are in junior high school. More specifically, the first and the second grades of junior high school are arguably serious turning points for their attitudes toward proactively studying English. The second biggest turning point is probably the first half of the first grade of senior high school, which was demonstrated by both Benesse Educational Research and Development Institute (2014) and the current survey. Once they have difficulty in learning English and begin to hate English, their feelings continue, even at the university level. On the other hand, when they do not have difficulties with the language, their positive attitude toward the language continues even when they are university students. The reasons why students dislike English are often related to the difficulties they have with the language. Some students feel that studying English equates to memorizing sentences and words, and learning English grammar is very difficult. In this light, it may be necessary to change the way English is taught in junior high school and senior high school, thereby finding appropriate measures to prevent students from developing negative attitudes towards English.

\section{References}

Benesse Educational Research and Development Institute. (2014). 中高生の英語学習に関する実態調査 2014 (The actual conditions of English learning motivations of junior high school students in 2014). Retrieved from http:// berd.benesse.jp/global/research/detail. php?id=4356

Benesse Educational Research and Development Institute. (2015). 第 5 回学習基本調査データブック 2015 (The 5th data book of basic research). Retrieved from http://berd.benesse.jp/shotouchutou/research/detaill. php?id=4801.

Dörnyei, Z. (2009). The L2 motivation self system. In Z. Dörnyei \& E. Ushioda (Eds.), Motivation, language identity and the L2 self, pp. 9-42. Bristol, UK: Multilingual Matters.

Hasegawa, S. (2013). 小学校英語の開始学年と指導形態の及 ぼす効果一熟達度テス卜と意識調査による比較検証一 - The effects of teaching style and initial grade of instruction in elementary school English education: A comparative test-and questionnaire-based study]. The Japan Association of English Teaching in Elementary Schools, 163-178.

Kikuchi, K., \& Sakai, H. (2016). Factors on changes of English learning motivation: A content analysis of motivating and demotivating experiences. JALT Journal, 38(2), 119-147.

Kiyota, Y. (2010). リメディアル教育における自尊感情と英語学 習 (Self-esteem and development English education). The Japan Association for Development Education, 5(1), 37-43.

Koike, M. (2013). 提言日本の英語教育ガラパゴスからの脱出 (Proposals for English education in Japan). Tokyo, Japan: Mitsumura Tosho.

Matsumiya, S. (2012). 早期英語教育が中等学校英語教育に及 ぼす影響についての調査研究 (Research regarding effects of elementary school English education on junior high school English education). Journal of Inquiry and Research, 95, 207-225.

Oka, H., \& Kanamori, T. (2009). 小学校英語教育の進め方 (How to conduct English education in elementary school). Tokyo, Japan: Seibido.

Sakai, C. (2009). 中学生の英語学習状況之学習意欲 (The Condition and motivation for junior high school students learning English). Retrieved from http://berd. benesse.jp/berd/center/open/report/chu_eigo/hon/pdf/ data_06.pdf

Sawyer, M. (2007). Motivation to learn a foreign language: Where does it come from, where does it go? Gengo-to-Bunka, 10, 33-42. 
Suemori, S., \& Sasashima, S. (2016). 大学生の可能自己と 英語学習一複雑性理論の可能生一 (University students' possible selves and language learning for university students: The potential for complexity theory). Jinbun Shakaigaku Ronshuu (Collections of the Humanities and Society), 34, 107-128.

Tatsuno, H. (2009). 科学的根拠で閉める 学習意欲を高め る 12 の方法 (12 methods to motivate students to learn based on scientific research). Tokyo, Japan: Toshobunka.

Tokuhashi, K., \& Misuochi, H. (2017). 教師の声かけが学 力低位層の生徒の学習意欲に与える効果に関する事例的 研究 (A case study on the effects of teachers' voices on learning motivation of lower-placed students: Changes of students in first grade English classes). Bull Teaching Profession Graduate School Joetsu Univ. Educ, 4, 149-159.
Yamamori, K. (2004). 中学校 1 年生の 4 月における英語学習 に対する意欲はどこまで持続するのか (How long do firstyear junior high school students keep their motivation toward English?). Kyoiku Shinrigaku Kenyuu (Educational Psychological Research), 52, 71-82.

Sumie Matsuno is an Associate Professor at Aichi Sangyo University College. She received her Ed.D in teaching English as a second language from Temple University, Japan. Her current research interests include peer-assessment, self-assessment, teacher-assessment, and English-language learners'

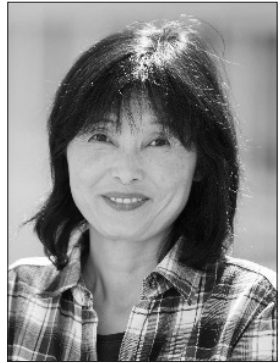
motivation.

\section{[JALT PRAXIS] TLT INTERVIEWS}
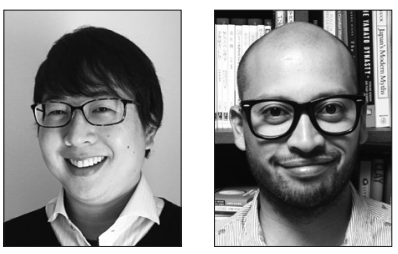

\section{Torrin Shimono \& James Nobis}

TLT Interviews brings you direct insights from leaders in the field of language learning, teaching, and education - and you are invited to be an interviewer! If you have a pertinent issue you would like to explore and have access to an expert or specialist, please make a submission of 2,000 words or less.

Email: interviews@jalt-publications.org

Welcome to the midsummer edition of TLT interviews! Our feature interview is with Hugh Starkey, Professor of Citizenship and Human Rights Education with the Institute of Education at the University of Central London. He has published widely on language teaching, cosmopolitan citizenship, and human rights education in a globalizing world. He is the co-founder and director of the International Centre for Education and Democratic Citizenship. Professor Starkey has also acted as a consultant to the Council of Europe, UNESCO, the European Commission, and the British Council. For the JALT2017 conference in Tsukuba, he gave a plenary speech entitled, "Cosmopolitan Citizenship and Language Learning." During the conference, he talked more in depth with Bob Ashcroft, a teacher in the Department of International Communication at Tokai University in Sapporo. Bob has a Master's Degree in Applied Linguistics from Birmingham University and a Diploma in English Language Teaching to Adults (DELTA). He has also taught in Poland, Germany, and Cambodia. Bob's research interests include CALL, vocabulary learning, and corpus linguistics. So, without further ado, to the interview!

\section{An Interview with Hugh Starkey Bob Ashcroft}

\section{Tokai University Sapporo}

Bob Ashcroft: What are your impressions of Japan?

Hugh Starkey: It's well-organized. That may be stereotypical but it's remarkably easy to get around. And, surprising things seem to happen. I feel there is great creativity and community spirit here.

Do stereotypes always have some truth in them?

I don't think they always have some truth in them, but they may be a starting point for reflection.

What's the problem with stereotypes?

They ascribe an identity to people we have never met. We assume something about a person we are in communication with on the basis of a prejudgment. Therefore, it's not usually helpful. It's best to 